Ryan Fackler, Christian Henrichson, Elizabeth Jànszky* and S. Rebecca Neusteter

\title{
Closing the Gap: The Need for Inclusive Benefit-cost Analysis in Policing
}

Abstract: This article first catalogs the curious lack of benefit-cost analysis (BCA) in policing, given the increasing use of BCA in other areas of criminal justice. Policing has historically been viewed through a benefit-only lens, focusing almost exclusively on the welfare gains associated with the incapacitation of dangerous offenders and the deterrence of future criminal activity. The benefit-only perspective fails to take into account the significant costs of enforcement. Most saliently, the benefitonly perspective limits the discussion of the costs to policing. We argue that BCA of policing should not be limited to the financial perspective of any municipality, but must include the full nonbudgetary social costs and benefits felt by all those who feel the impact of policing. Social costs should include all direct and indirect costs borne by members of society who are impacted by policing practices in addition to costs that appear in police department budgets.

Keywords: Benefit-Cost Analysis; Policing; Social Costs.

JEL classifications: K000; K420; H760; D61.

\section{Introduction}

During the past decade, benefit-cost analysis (BCA) has increasingly been used to evaluate criminal justice policies and programs. This growth has, in part, been "demand driven," as cash-strapped states have turned to BCA to examine how they can most effectively spend their over-extended budgets. Between 2008 and 2011, the number of state governments conducting BCA increased from 25 to 37 , and the number of studies produced by these states increased by $79 \%$, from 62 to 111 (The Pew Charitable Trusts, 2013; White \& VanLandingham, 2015).

Ryan Fackler: New York University School of Law, Law, 40 Washington Square S., NY 10012, USA

Christian Henrichson: Vera Institute of Justice, 233 Broadway \#12, NY 10279, USA *Corresponding author: Elizabeth Jànszky, New York University School of Law, 40 Washington Square S., NY 10012, USA, e-mail: egj212@nyu.edu

S. Rebecca Neusteter: Vera Institute of Justice, 233 Broadway \#12, NY 10279, USA 
Foundations and governments have also shown increased interest in criminal justice BCA. The Pew/MacArthur Results First Initiative, which works with states and counties to replicate the Washington State Cost-Benefit Model, was founded in 2011 through the Pew Charitable Trusts and the MacArthur Foundation, and the U.S. Department of Justice, Bureau of Justice Assistance funded the Vera Institute of Justice's Cost Benefit Knowledge Bank for Criminal Justice between 2009 and 2013. Furthermore, the U.S. National Institute of Justice has been encouraging grant applicants to consider the use of BCA, sometimes giving preference to applications that use BCA (U.S. National Institute of Justice, 2013, 2016).

\section{Benefit-Cost Analysis and Policing}

The use of BCA to evaluate policing practices, however, has been scant, despite a decade-long effort to proliferate the use of criminal justice BCA. There is perhaps no better evidence of this gap than the limited number of policing studies in the expansive portfolio of justice BCA conducted by the Washington Institute for Public Policy (WSIPP). Only four of the 49 adult criminal justice investments examined by the WSIPP are for policing programs and policies, and none of the 30 juvenile justice investments they examined pertain to policing. ${ }^{1}$

The paucity of BCA in policing is conspicuous considering the amount spent on policing in the United States. Nationwide, nearly as much money is spent on policing ( $\$ 121$ billion) as corrections ( $\$ 81$ billion) and the judiciary system ( $\$ 55$ billion) combined (U.S. Bureau of Justice Statistics, 2013). Furthermore, the relative merits and drawbacks of emerging policing technologies - such as body-worn and dashboard cameras, predictive policing software, computer-aided dispatch systems - and practices - such as proactive patrolling, and stop and frisk - are debated without any concrete data on the benefits and costs. Rather, based on our observations, decision-making seems to be generally shaped by the available budgetary resources, the police agency's preference, procurement rules, and occasionally by anecdotal accounts of the costs and benefits.

When BCA of policing is formally conducted, frequently, the costs considered are limited strictly to the budgetary costs of implementation. A meta-analysis by Horowitz and Zedlewski (2006) of all law enforcement evaluations commissioned by the National Institute of Justice between 1994 and 2004 found that less than one third of reported evaluations "contained the minimal data necessary to support

1 Authors' analysis of benefit-cost studies summarized on WSIPP's website. See http://www.wsipp.wa .gov/BenefitCost (Accessed August 14, 2017). 
cost-benefit analyses" (p. 55). A more recent meta-analysis of crime prevention programs by Welsh, Farrington and Gowar (2015) concluded that "benefit-cost analysis continues to be underused in the study of crime prevention," but that the quality of the analysis is rapidly improving (p. 448). Both of these reviews, however, highlight a narrow focus on costs, limiting them principally to operational expenses. This narrow focus is expanding in more recent cost-of-crime literature, with Donohue (2009), for example, discussing but not estimating a broader set of social costs and benefits. This view must expand further, and especially into the cost side of the analysis.

\section{The Social Costs of Policing}

The lack of BCA in policing is not only strange; it is disconcerting. Policing has historically been analyzed by considering its benefits, placing the greatest weight on the welfare gains associated with the incapacitation of dangerous offenders and the deterrence of future criminal activity (Becker, 1968; Shavell, 1987; Polinsky $\&$ Shavell, 2007). The major costs generally considered have primarily been the public budgetary expenditures (Polinsky \& Shavell, 2007). While these benefits and costs are fundamental components to consider when determining the optimal level of any police practice, this perspective fails to take into account many significant costs of enforcement. First-order costs of policing refer to the costs incurred by the government should an individual be stopped, arrested, tried, and convicted for a crime; pretrial proceedings and prison expenses are included. First-order costs also include the costs incurred by innocent individuals who are stopped in traffic or on the street (Cohen 2017, this issue). Second-order costs, although more difficult to quantify, are equally important considerations. These types of costs include family instability, diminished job prospects, dignitary harms from wrongful incarceration, loss of income, and a host of other considerations that result from enforcement. These second-order costs accrue both directly to those ultimately arrested, tried, and convicted of a crime (e.g. diminished job prospects) and also to those who may never make direct contact with the police (e.g. family instability).

We provide two arguments for why arrest, incarceration, and second-order costs should be included in any BCA of policing. First, an analysis can be conducted from the point of view of at least three entities: (1) the police department, (2) the local government, or (3) society broadly defined. We argue that BCA from society's perspective is the most appropriate for facilitating - only society's 
perspective is conceptually valid. This perspective incorporates all costs of policing and provides the most complete picture of the consequences produced. ${ }^{2}$

Second, inclusion of these costs helps to overcome the social planner's dilemma inherent in policing. The process around policing decisions is normally quite onesided, with tough-on-crime rhetoric being the consistent theme (Dripps, 1993; Stuntz, 2001; Barkow, 2005; Friedman \& Ponomarenko, 2015), although we should note that the discussion has been beginning to shift in the last few years (Bauer, 2014; Malcolm, 2015). The problem with such an approach, however, is that it ignores the very real tangible and intangible costs of policing, especially to the minority population that is most impacted by its negative consequences. Not surprisingly, this group is often the most politically weak in a community, and has little opportunity to offset the inequities in discussions about policing (Harmon, 2015). Harmon (2015), for example, states that because only a small percentage of the population is searched, arrested, or really has any interaction with the police, there is a "decoupling between the population that experiences the benefits of policing - which are widely distributed - and the population that pays its costs, which are concentrated on a smaller, politically weak minority, including criminal suspects" (p. 941). Incorporation of the arrest, incarceration, and collateral costs of a police practice, therefore, will provide a voice to those who have been excluded from decisions surrounding policing programs.

To begin the discussion on whether the arrest, incarceration, and other potential social costs should be included in a BCA on policing, we must first decide the point of view from which the BCA is being conducted. We argue that use of the perspective of the police department or local government is not a sufficient perspective for a BCA in policing. Instead, a BCA of policing should include all members of a society. "Society" does not necessarily mean the whole world. In many circumstances, it makes sense to conduct a BCA restricting society to all members of a neighborhood, city, town, state, or country. Instead, we are distinguishing the police department or local government's parochial or budgetary interests from the interests of all individuals overseen by the police or government.

As agents of the state, police departments and governments have no intrinsic perspective. ${ }^{3}$ To see this, we simply have to ask what the goals of the department (or the government) are for policing - chiefly, to identify and apprehend individuals guilty of committing crimes and to deter others from committing crimes. These

2 For a comprehensive discussion of the framing of BCA, see Boardman, Greenberg, Vining and Weimer (2011).

3 The individual members of a department certainly have a perspective - to reduce crime, to advance in rank, to avoid punishment, to come home alive. By "intrinsic perspective" we mean that the department itself has no perspective. The department's enforcement goals are imposed upon it by a legislature or city council, but are not generated organically and independently. 
objectives are imposed on the department and government because members of society incur substantial costs from crime and because society values prosecution for violating its laws, and wants to deter future crimes (Posner, 1985; Alschuler, 2003). Thus, the institutions only pursue such goals because society as a whole places great weight on them.

Conducting a BCA of policing from the perspective of all members of society, on the other hand, provides a more complete and objective picture of the full range of consequences of such a program, and allows society to make the most informed estimation of whether the police practice improves social welfare. Accordingly, a BCA should include not just the direct, financial costs incurred by the state for arrest and incarceration, but also the other social costs and benefits felt by an individual's family, friends, and employer ("second-order effects") Cohen (2017). Removing a loving father from a family, for example, potentially eliminates a major source of stability and income, which may have long-term ramifications for his partner and children. $^{4}$

There is evidence of intergenerational punishment costs. Andersen and Wildeman (2014) document the rise in foster care rates directly caused by parental incarceration, controlling for factors such as family finances or divorce. Parental incarceration hurts children's health and school attendance (Geller, Cooper, Garfinkel, Schwartz-Soicher \& Mincy, 2012; Turney, 2014; Porter \& King, 2015). Evidence exists that parental incarceration has led to increases in children's future criminality, a direct long-term cost to society (Andersen, 2016).

There is also a substantial literature discussing the criminogenic nature of incarceration; that is, that the act of incarcerating itself causes an individual to commit more future crimes. ${ }^{5}$ These costs, too, must be incorporated into a BCA, as they represent predictable expected costs to society. For example, suppose that there was a police department that developed technology to perfectly detect whether there were illegal drugs in someone's car. If the punishment for drug possession is some incarceration, and we assume that the evidence of criminogenic effects is accurate, then an arrest and incarceration for drug possession today will produce more crimes per person in the future (Heaton, Mayson \& Stevenson, 2017). Therefore, a BCA of deploying this new technology should include the criminogenic effects as a cost of the program, and must be compared with the counterfactual effects of not arresting

\footnotetext{
4 As discussed later, the costs a policing strategy includes on ex post innocent individuals. These costs, while important, and in the context of programs such as stop and frisk, potentially primary, are direct, first-order costs.

5 For example, Heaton, Mayson \& Stevenson (2017) find that while pretrial "detention exerts an incapacitative effect in the short term, by 18 months posthearing, detention is associated with a $30 \%$ increase in felonies and a $20 \%$ increase in misdemeanors, a finding consistent with other research suggesting that even short-term detention has criminogenic effects" (p. 718).
} 
for illegal drugs but potentially only issuing a summons. ${ }^{6}$ As discussed more extensively by Heaton et al. (2017), the BCA should be careful to present the uncertainty about long-term consequences to incarceration, but presenting uncertainty should not mean ignoring situations with any uncertainty.

In addition to the second-order effects felt by friends, family, and the employer, certain police practices have potentially enormous "third-order" effects to unrelated parties. Expansion of the use of a policing practice may impose psychological costs on members of society who have not directly interacted with the police themselves (Geller, Fagan, Tyler \& Link, 2014). These psychological costs, in turn, reduce the legitimacy of the police force as a whole, which, in turn, reduces police efficiency (Cohen, 2017). Interestingly, as discussed more extensively by Geller (2017), these costs are not necessarily inherent to a police practice, but depend on how the police comport themselves. For example, a traffic stop may impose substantially different psychological costs depending on whether the officer is aggressive or calm during the interaction.

The outstanding question is whether we should include the second-order costs - such as loss of income and dignitary harms - experienced by the "rightfully" arrested and incarcerated individual himself ("first-order effects"). These costs are fundamentally different from the arrest and incarceration costs of those who are not guilty of any offense, of which there are many (Cohen, 2017), ${ }^{7}$ and from the indirect costs felt by the rest of society, and as such, we see two main ways to think about them.

First, a straightforward application of rational agent economic theory would likely make a revealed preference argument that a criminal rationally weighs all of the costs and benefits to crime. The criminal incorporates all costs the individual may experience from committing the crime into his or her analysis and still decides that the potential benefits of crime outweigh the potential costs. Therefore, we can ignore the criminal's expected costs because they are inherently balanced by the criminal's expected benefit from committing the crime. Second, unlike all other costs being discussed, these costs could be understood as an intentional punishment for the crime committed. This punishment benefits society not just through a pursuit of justice, but as the mechanism of deterrence. Insofar as punishment acts as

6 This is beyond the scope of the paper, but it is interesting to note that our hypothetical case suggests that results from a BCA of a policing program could lead to the conclusion that it is inefficient for departments to police certain crimes at all. What police departments would do with such information is unclear, but should they refuse to police those crimes, the BCA would effectively become a choice to decriminalize an activity that sidesteps formal legislative deliberations.

7 Take, for example, NYPD's stop and frisk program, in which 90\% of the 191,558 stopped in 2013 were found innocent (New York's Stop-and-Frisk Policy Ineffective in Recovering Guns, Stopping Murders - Report, RT (Accessed August 21, 2014, 6:12 PM), http://rt.com/usa/181976-stop-frisk-ineffectiv e-guns/). 
a deterrent, the costs incurred by the arrested individual should be included and ideally balanced by the benefit society derives from the deterrence (for a meta-analysis of the existing literature on deterrence, see Braga and Weisburd 2011).

Aside from these questionable second-order costs, we think that the first-order costs to individuals who are not guilty of any offense should be included in a BCA of policing. Although it is difficult to pinpoint a precise approximation of how many individuals are wrongfully arrested and convicted every year, it is clear that these two events do occur, and with some frequency. ${ }^{8}$ For example, Gross, O’Brien, $\mathrm{Hu}$ and Kennedy (2014) estimate that $4.1 \%$ of death sentences in the United States are a result of wrongful convictions. Because the arrest and incarceration of innocent individuals represents an undeserved punishment that is not countered by society's desire for justice or deterrence, a BCA on a police practice should include these direct social costs of those wrongfully arrested and convicted. It would also be useful to include expected legal costs of wrongful arrest and incarceration, which can rise to millions of taxpayer dollars. ${ }^{9}$

Ideally, every one of the above discussion's costs and benefits should be estimated and included in any BCA of policing, but it is fundamentally infeasible to measure everything. The choice of what costs and benefits to include in a BCA must be made ex ante in anticipation of the potential magnitudes, and must be tailored to the specific policy in question. Difficulty of measurement, however, is no excuse. Incorporation of BCA in policing practices is essential to understanding, and improving, law enforcement in the United States. If we do not consider the totality of the consequences of a policing program, it is impossible to determine whether policing is actually doing what it is supposed to do - efficiently maximizing public safety and the welfare of society. Inclusion of both the benefits all members of society will receive by increased public safety as well as the direct and indirect costs that they will incur is the only way to provide useful information about what works and what does not when it comes to policing, and to find the best policy option out of the available alternatives.

\footnotetext{
8 In some contexts, the first-order collateral costs from the arrest and incarceration of innocent individuals may be the most salient, but they should not be considered as the only first-order costs. Individuals who are stopped and frisked without any warning, ticket, or arrest have incurred direct time and dignitary costs that cannot be justified by appeal to a rational agent's choice or a punishment for wrongdoing.

9 For example, New York City recently paid \$75 million to settle an NYPD summons suit (Ramey \& Kanno-Youngs, 2017), and the famous Central Park Five wrongful conviction resulted in a \$40 million settlement (Weiser, 2014).
} 


\section{References}

Alschuler, Albert (2003). The Changing Purposes of Criminal Punishment: A Retrospective on the Past Century and Some Thoughts About the Next. University of Chicago Law Review, 70, 1-22.

Andersen, Lars H. (2016). How Children's Educational Outcomes and Criminality Vary by Duration and Frequency of Paternal Incarceration. The ANNALS of the American Academy of Political and Social Science, 665(1), 149-170.

Andersen, Signe H. \& Wildeman, Christopher (2014). The Effect of Paternal Incarceration on Children's Risk of Foster Care Placement. Social Forces, 93(1), 269-298.

Barkow, Rachel E. (2005). Federalism and the Politics of Sentencing. Columbia Law Review, $105,1226-1314$.

Bauer, Shane H. (2014). How Conservatives Learned to Love Prison Reform. Mother Jones, available at http://www.motherjones.com/politics/2014/02/conservatives-prison-refor m-right-on-crime/.

Becker, Gary S. (1968). Crime and Punishment: An Economic Approach. Journal of Political Economy, 76, 169-217.

Boardman, Anthony E., Greenberg, David H., Vining, Aidan R. \& Weimer, David L. (2011). Cost-Benefit Analysis: Concepts and Practice. London: Pearson.

Braga, Anthony A. \& Weisburd, David L. (2011). The Effects of Focused Deterrence Strategies on Crime: a Systematic Review and Meta-analysis of the Empirical Evidence. Journal of Research in Crime and Delinquency, 49(3), 323-358.

Cohen, Mark A. (2017). The Social Cost of a Racially Targeted Police Encounter. Journal of Benefit-Cost Analysis, 8, 339-384.

Donohue, John J. (2009). Assessing the Relative Benefits of Incarceration: Overall Changes and the Benefits on the Margin. In Stevens Raphael \& Michael A. Stoll (Eds.), Do Prisons Make Us Safer? The Benefits and Costs of the Prison Boom (pp. 269-342).

Dripps, Donald A. (1993). Criminal Procedure, Footnote Four, and the Theory of Public Choice; or, Why Don't Legislatures Give a Damn About the Rights of the Accused? Syracuse Law Review, 44, 1079-1101.

Friedman, Barry \& Ponomarenko, Maria (2015). Democratic Policing. New York University Law Review, 90, 101-183.

Geller, Amanda (2017). Benefit-Cost Analysis in Policing Research: Assessing CrimeControl Benefits of Proactive Enforcement Practices. Journal of Benefit-Cost Analysis, 8, 339-347.

Geller, Amanda, Cooper, Carey E., Garfinkel, Irwin, Schwartz-Soicher, Ofira \& Mincy, Ronald B. (2012). Beyond Absenteeism: Father Incarceration and Its Effects on Children's Development. Demography, 49(1), 49-76.

Geller, Amanda, Fagan, Jeffrey, Tyler, Tom \& Link, Bruce G. (2014). Aggressive Policing and the Mental Health of Young Urban Men. American Journal of Public Health, 104(12), 2321-2327.

Gross, Samuel R., O’Brien, Barbara, Hu, Chen \& Kennedy, Edward H. (2014). Rate of False Conviction of Criminal Defendants Sentenced to Death. Proceedings of the National Academy of Sciences, 111, 7230-7235.

Harmon, Rachel (2015). Federal Programs and the Real Costs of Policing. New York University Law Review, 90, 870-960.

Heaton, Paul, Mayson, Sandra \& Stevenson, Megan (2017). The Downstream Consequences of Misdemeanor Pretrial Detention. Stanford Law Review, 69, 713-794. 
Horowitz, Jake \& Zedlewski, Edwin (2006). Applying Cost-Benefit to Policing Evaluations. Justice Research and Policy, 8(1), 51-65.

Malcolm, John G. (2015). Why Conservative Governors are Embracing Criminal Justice Reform. The Daily Signal, available at http://dailysignal.com/2015/08/04/why-conserv ative-governors-are-embracing-criminal-justice-reform/.

Pew-Macarthur Results First Initiative (2013). States' Use of Cost-Benefit Analysis: Improving Results for Taxpayers. Philadelphia, PA: The Pew Charitable Trusts; http://www.p ewtrusts.org/ /media/legacy/uploadedfiles/pcs_assets/2013/pewresultsfirst50staterepo rtpdf.pdf.

Polinsky, A. Mitchell \& Shavell, Steven (2007). The Theory of Public Enforcement. In Handbook of Law and Economics. Amsterdam: Elsevier.

Porter, Lauren C. \& King, Ryan D. (2015). Absent Fathers or Absent Variables? A New Look at Paternal Incarceration and Delinquency. Journal of Research in Crime and Delinquency, 52(3), 414-443.

Posner, Richard A. (1985). An Economic Theory of Criminal Law. Columbia Law Review, $85,1193-1231$.

Ramey, Corinne \& Kanno-Youngs, Zolan (2017). New York City to Pay up to \$75 Million to Settle NYPD Summons Suit. Wall Street Journal, https://www.wsj.com/articles/new -york-city-to-pay-up-to-75-million-to-settle-nypd-summons-suit-1485211215.

Shavell, Steven (1987). A Model of Optimal Incapacitation. American Economic Review, 77, 107-110.

Stuntz, William J. (2001). The Pathological Politics of Criminal Law. Michigan Law Review, $100,505-600$.

Turney, Kristin (2014). Stress Proliferation Across Generations? Examining the Relationship between Parental Incarceration and Childhood Health. Journal of Health and Social Behavior, 55(3), 302-319.

U.S. Bureau of Justice Statistics (2013). Employment and Expenditures. Washington, DC: United States Department of Justice; Office of Justice Programs. https://www.bjs.gov/i ndex.cfm?ty $=$ tp\&tid $=5$.

U.S. National Institute of Justice (2013). The Impact of Probation/Parole Officer Home Visits on Offender Outcomes. Washington, DC: United States Department of Justice; Office of Justice Programs. https://www.ncjrs.gov/pdffiles1/nij/s1001034.pdf.

U.S. National Institute of Justice (2016). Investigator-Initiated Research \& Evaluation on Firearms Violence. Washington, DC: United States Department of Justice: Office of Justice Programs; https://nij.gov/funding/Documents/solicitations/NIJ-2016.-9091.pdf.

Weiser, Benjamin (2014). 5 Exonerated in Central Park Jogger Case Agree to Settle Suit for \$40 Million. New York Times, (https://www.nytimes.com/2014/06/20/nyregion/5-exon erated-in-central-park-jogger-case-are-to-settle-suit-for-40-million.html?_r=1).

Welsh, Brandon C., Farrington, David P. \& Gowar, B. Raffan (2015). Benefit-Cost Analysis of Crime Prevention Programs. Crime and Justice, 44(1), 447-516.

White, Darcy \& VanLandingham, Gary (2015). Benefit-Cost Analysis in the States: Status, Impact, and Challenges. Journal of Benefit-Cost Analysis, 6(2), 369-399. 